Growth, Centrism and Semi-Presidentialism:

Forecasting the Portuguese General Elections

\author{
Pedro C. Magalhães ${ }^{1}$ \\ Social Sciences Institute of the University of Lisbon \\ Av. Prof. Aníbal de Bettencourt, 9 \\ 1600-189 Lisbon, Portugal \\ Luís Aguiar-Conraria \\ Department of Economics of the University of Minho \\ Campus de Gualtar \\ 4710-057 Braga, Portugal
}

\begin{abstract}
Electoral behaviour in recently established democracies has been more frequently treated from the point of view of its unpredictability, volatility and personalistic elements than that of its "fundamentals". In this paper, we wish to contribute to redress this imbalance by advancing a forecasting model for general elections in a young democracy, Portugal. Building on the very familiar notion that the vote for the incumbent can be predicted on the basis of "economics" and "politics", we capture "economics" through a nonlinear specification of economic growth. Furthermore, we include two structural features of Portuguese politics, which have entailed a systematic electoral punishment for the centre-left Socialist Party as the incumbent and for all incumbents involved in political conflicts with the elected president in Portugal's semipresidentialism.
\end{abstract}

\title{
Keywords
}

Forecasting; Portuguese general elections; Economics and elections; SemiPresidentialism

\footnotetext{
${ }^{1}$ Corresponding author. E-mail address: pedro.magalhaes@ics.ul.pt; Tel.:+351-21-7804700; Fax.:+35121-7940274.
} 


\section{Growth, Centrism and Semi-Presidentialism: Forecasting the Portuguese General Elections}

\section{Introduction}

One of the often noted traits of elections in the "third-wave" democracies is the high level of uncertainty regarding electoral outcomes (Mainwaring and Torcal, 2006: 221), a consequence of low levels of party system institutionalization, high electoral volatility, the shallow anchoring of the vote in ideological or partisan predispositions and the prevalence of personalistic voting.

According to most of the literature, Portugal is not an exception to this pattern. Individual voting behaviour is weakly explained by stable social cleavages and electoral volatility has been extremely high ever since democratization in the 1970s (Gunther and Montero, 2001). Affect towards party leaders has been shown to play an extremely strong role in voting choices (Lobo, 2006). Positions on most issues - with the exception of the economy - play a modest and rather confusing role in electoral behaviour (Freire, 2007). Although pre-election polls conducted in the week immediately before the elections seem to converge to relatively accurate results, those conducted few weeks or months before election day display wide divergences and fluctuations, suggesting a very late crystallization of the vote and large numbers of late deciders (Magalhães, 2005). Accordingly, discussions and explanations of concrete election outcomes in Portugal typically place great stock in campaign events, media coverage, and leaders' traits and personalities (Lloyd-Jones, 2001; Salgado, 2007).

All this, together with the inevitably small number of observations of democratic election outcomes, has probably served to dissuade scholars from attempting to devise models forecasting election results in recently established democracies. A look at the English-language literature on election forecasting in scientific journals reveals that, 
outside the United States - where a vast literature on the subject has been published since the $1970 s^{1}$ - only in cases such as the United Kingdom, France and Germany have such models been commonly proposed. ${ }^{2}$ However, there are, prima facie, some reasons to believe that, among "third-wave" democracies, Portugal is perhaps one of the cases where attempts at election forecasting are more promising. On the one hand, from 1975 until today, already twelve general legislative elections have been conducted, providing a number of observations for analysis that, albeit very small, is in any case larger than in any other "third-wave" democracy. On the other hand, Portugal's party system, political institutions and structure of electoral competition have provided a contextual setting where the basic assumptions of most forecasting models are closely approximated. With a small number of effective parliamentary parties, ${ }^{3}$ basic alternation in power between a large centre-right (the Social Democratic Party, PSD) and a large centre-left party (the Socialist Party, PS), a unicameral "arena" parliament, strong intraparty discipline and a president lacking effective veto-powers (Magalhães, 2003), elections in Portugal do tend to exhibit the kind of "clarity of responsibility" and the direct link with the allocation of executive power that most forecasting models tend to assume.

In this article, we will suggest that, in fact, electoral outcomes in Portugal end up being quite predictable within a reasonably small margin of error. We formulate a vote function model to forecast the percent share obtained by the incumbent party in Portuguese general elections. We rely on the basic familiar notion in such forecast models: that the vote for the incumbent party is a function of "economics" and

\footnotetext{
${ }^{1}$ For reviews, see, for example, Lewis-Beck and Rice (1992), Lewis-Beck (2005), and Campbell (2008).

${ }^{2}$ For the UK, see, among many others, Whiteley (1979), Mughan (1987), the symposiums of papers published in Electoral Studies (vol. 23, issue 2) and the British Journal of Politics and International Relations (volume 7), and, more recently, Lebo and Norpoth (2008) and Whiteley (2008); for France, see, for example, Jérome and Jérome-Speziari (2004) and Lewis-Beck, Bélanger and Fauvelle-Aymar (2008); for Germany, see Norpoth and Gschwend (2003).

${ }^{3}$ In the twelve elections since 1975, the average "effective number of parliamentary parties" (Laakso and Taagepera, 1979) is 2.8 .
} 
"politics". However, we implement such notion in a somewhat less familiar way. On the one hand, without abandoning the idea that elections are, to some extent, a referendum on economic performance, we suggest that a non-linear specification of economic variables provides a more realistic approach to the way they actually play out on election outcomes. On the other hand, out of necessity, we end up replacing the common use of "government popularity" or "voting intention" survey-based indicators with other variables that, in fact, may actually end up bringing us closer to the political "fundamentals" in Portuguese electoral behaviour. One of those variables addresses a basic asymmetry between the left and the right of the Portuguese party system and the way that asymmetry entails a structural electoral punishment for centre-left governments. Another derives from the importance of the presidential office in the Portuguese "premier-presidential” brand of semi-presidentialism (Shugart, 2006).

\section{The model}

Many (if not most) aggregate vote function models include some measure of lagged economic performance (Lewis-Beck, 2005; for seminal contributions, see Kramer, 1971 and Fair, 1978). There are good reasons to do the same in the case of Portugal. Research using aggregate survey data on aggregate government popularity or voting intentions suggests that voters are retrospective, punishing or rewarding government parties on the basis of past economic performance (Veiga and Veiga, 2004a and 2004b). Studies based on the impact of actual economic conditions (rather than individual perceptions) on individual-level behaviour confirm this notion and show that Portugal is one of the European Union countries where the electoral effects of the economy are largest (van de Brug, van der Eijk and Franklin, 2007). Finally, confirming existing theorization (Hibbs, 1977; Powell and Whitten, 1993), not all leading economic 
indicators have the same effect on support for different government parties in Portugal: while support for left-wing governments is mostly affected by unemployment, the effects of inflation are highest for right-wing ones (Veiga and Veiga, 2004a).

Modelling the latter effects, using interactions between economic indicators and dummy variables for the ideological leaning of the parties in government, would probably be closer to ideal for our purposes. However, this is a luxury that we cannot afford in this particular case. First, unemployment data before the 1980s in Portugal is notoriously unreliable. Second, with so few observations of election results, this would entail a fatal reduction in degrees of freedom. Thus, we choose to employ a single measure of economic performance: the yearly real GDP growth, measured with a lag of two quarters in relation to the one when the election took place. ${ }^{4,5}$

Furthermore, we submit that a non-linear transformation of the economic growth variable provides a more realistic approach to the way voting behaviour is likely to be affected by economic performance. If we had simply included the growth rate as an explanatory variable we were implicitly assuming that a change of the growth rate from 0 to 1 percent had the same impact as a change from 9 to 10 percent. This assumption is hardly justifiable. While the latter change is likely to make little difference in the public perception of very high economic growth rates, the former represents the difference between stagnation and (albeit low) growth. Thus, instead, we consider a non-linear monotonic transformation of the growth rate that allows the model to puff up the effect of growth rate changes when the growth rate is small. Let $X_{t}$ be the growth rate (in

\footnotetext{
${ }^{4}$ Source: OECD. We also tried different lag structures. Predictably, the worst fit - and a statistically insignificant coefficient - was obtained with real yearly GDP growth measured up to the end of the quarter where the election took place. Lags of one or three quarters provided better results, but both worse than the two-quarter lag.

${ }^{5}$ The other economic variable that is typically used in these kinds of studies is inflation. This variable was statistically not significant at the conventional levels.
} 
percentage terms) and $\max (\mathrm{X})$ the highest observed growth rate. Instead of $\mathrm{X}_{\mathrm{t}}$, we use the transformation $Y_{t}=\operatorname{sign}\left(X_{t}\right)\left(\frac{\left|X_{t}\right|}{\max (X)}\right)^{\alpha} * \max (X)$.

It is clear that for $\alpha$ smaller than one, when the growth rate is closer to zero, the impact of changes in the growth rate is magnified. As we explain later, we estimate the value of $\alpha$ to be 0.633 . Given this estimate, an increase of $X_{t}$ from 4 to 5 implies a change of $Y_{t}$ from 4.51 to 5.2; while an increase of $X_{t}$ from 0 to 1 implies a change of $Y_{t}$ from 0 to 1.88 , almost three times larger. See Figure 1 for graphical illustration of this effect (given our data, we assumed $\max (X)=5.55$ ).

\section{Figure 1 about here}

In election forecasting models, measures of economic performance tend to be combined with some measure of how government has performed in other issues, more commonly, government popularity. In the Portuguese case, practical considerations exclude the use of such indicators from our model: there is no reliable government or prime-ministerial popularity poll data in Portugal before 1986 (Veiga and Veiga, 2004a). Including such a variable in the model would thus lead us to lose five observations, another luxury we cannot afford.

It may be the case, however, that our inability to employ such an indicator ends up being a blessing in disguise. In the forecasting literature, there is considerable discussion about the adequate balance between purely predictive and explanatory goals. While some see no reason not to employ the best available data to obtain the most accurate predictions - such as, for example, results of trial-heat polls conducted close to the election (Campbell, 2000) - others worry about near-tautological consequences of "placing the dependent variable on the right-hand side of the equation" (Lewis-Beck, 
2005: 155). This begs the question, however, of the extent to which the use of government popularity measures, even if lagged, as a predictor of the vote, is itself able to evade such near-tautology (van der Eijk, 2005). In any case, regardless of how one stands in that particular debate, our practical inability to use popularity data creates, at the very least, an interesting challenge. If we are indeed able to produce reasonably accurate forecasts of the vote without resorting to poll data on popularity or voting intentions collected close to the elections themselves, having been forced to specify the "political" elements of the model in a different way, it is possible that we end up coming closer to the objective fundamentals of what explains elections results, rather than relying on attitudinal variables that may be themselves affected by those fundamentals.

We thus propose two political variables, one related to particular features of electoral competition and the party system in Portugal and another to he country's political institutions. First, an interesting result of studies using time-series data on aggregate government popularity and voting intention for the incumbent in Portugal is that, when all other economic and institutional factors are held constant, the coefficient for a "Socialist Party" dummy (with PSD as the reference category) is negative and significant (Veiga and Veiga 2004a and 2004b). There are good reasons for such a pattern to emerge. Unlike what occurs in the right of the party system, where the voters' option between the PSD and the CDS-PP tends to be made mostly on the basis of strategic grounds and leader evaluations, choices within the left block are more strongly based in social and ideological grounds (Lobo, 2006). ${ }^{6}$ Furthermore, the Portuguese Socialist Party has, since its very inception, functioned as catch-all party and adopted centrist policies while in government. Unencumbered by links to the labour movement

\footnotetext{
${ }^{6}$ For the distant origins of these patterns, see, for example, Gunther (2005).
} 
and involved in an enduring struggle against the Communist Party (PCP) first, for regime democratization and, later, for the liberalization of the a highly statist economy, the PS was often placed in a dilemma that, at the right, the PSD was able to avoid: its success in attracting and sustain a centrist electorate was often counterbalanced, following incumbencies, by losses to leftist parties (the PCP first, and later also to the newly created Leftist Block - BE). ${ }^{7}$

One consequence of this is visible when we analyze the ideological composition of the PS electorate through time: while the successful bids for power of the Socialists have always entailed the ability to attract the strategic vote of part of the leftist electorate, their passage through government was always followed by a desertion of segments of that same electorate to the parties in the left (Gómez Fortes, 2007). In some cases -1999 , for instance - good economic performance and the corresponding afflux of centrist voters seems to have been enough to compensate such losses. However, ceteris paribus, as an incumbent party, the PS seems to be more affected by desertions of leftist voters than the PSD is affected by desertions of rightists. Thus, the second variable in our model is a dummy variable with value 1 when the incumbent was the PS: we expect a negative sign, representing the structural punishment endured by the Socialists after incumbency that follows from this particular structure of party competition.

Second, we take into account the semi-presidential nature of the Portuguese government and the particular role played by the president in the political system. Unlike what occurs in the French case, where the president is the de facto head of the parliamentary majority (Thiébault, 2003), or in established cases of "presidentparliamentarism" (Shugart, 2006), Portugal's brand of semi-presidential government

\footnotetext{
${ }^{7}$ In 1985, the short-lived Partido Renovador Democrático (PRD), generally perceived to be to the left of the PS, was also arguably also the recipient of defections from the PS.
} 
has (with the exception of a brief stint from 1978 to 1979 of three short-lived cabinets of "presidential initiative") never placed the popularly elected President in control of executive power. However, Portuguese presidents have also typically enjoyed and exerted more powers than their counterparts in other semi-presidential systems such as Ireland, Austria, or Iceland, where candidates tend to be recruited among minor party figures or "political outsiders" and elected presidents tend to play a mostly ceremonial and symbolic role (Kristinsson, 1999; Müller, 1999). Instead, Portuguese presidents - as well their counterparts in many Eastern European semi-presidential systems - occupy somewhat of a middle ground in terms of presidential intervention in politics in comparison with those two extremes (Neto, 2003). Even after a reduction of powers obtained through a 1982 constitutional amendment, Portuguese presidents can dissolve parliament, refer bills for constitutional review, and veto legislation. And although vetoes can be overridden by a parliamentary majority and constitutional referrals are of uncertain efficacy as veto-points, the public visibility brought to bear on government policies in this way can entail political costs that provide presidents with some leverage vis-à-vis governments, and can even be used in "wars of attrition" against them in situation of premier-presidential conflicts (Magalhães, 2007).

Such conflicts have, in fact, happened recurrently not only in Portugal (Frain, 1995) but also in several Eastern European semi-presidential systems (Baylis, 1996; Protsyk, 2005 and 2006). We expect them to entail important electoral consequences for incumbent parties. Elected by majority run-off systems, presidents obtain shares of the vote typically larger than that of any single party in a proportional representation system. The popular legitimacy derived from this provides not only justification for enhanced intervention in politics (Duverger, 1980; Protsyk, 2005), but also an initial reservoir of support that, in cases of conflict with governments, is only slowly 
extinguished: as they lack formal executive powers and tend to be seen as "above" everyday politics, presidents' opposition to incumbent prime ministers tends to be perceived benevolently by more voters than those who would support the actions of a purely partisan political actor.

Thus, we argue that one crucial variable explaining the electoral performance of incumbent parties is the existence of such open and public conflicts between presidents and prime-ministers. Several Portuguese elections were held following such periods: the 1979, 1980, 1983 and 1985 elections, a protracted period of terse relations between Ramalho Eanes and the several centre-right and centre-left governments (Bruneau and Macleod, 1986); the 1995 elections, following the conflict between Mário Soares and the PSD majority government (Corkill, 1996); and the 2005 elections, following the dissolution of parliament and consequent fall of the centre-right coalition formed by the PSD and the smaller rightist CDS-Popular Party (Salgado, 2007). We thus created a simple dummy variable, coded 1 for those elections, and expect it to have a negative sign: incumbents are likely to be punished in elections that follow periods of premierpresidential conflict.

In short, then, we propose a simple forecast model for the Portuguese general elections:

$$
V O T E=\mathrm{B}_{0}+\mathrm{B}_{1} \text { GROWTH }+\mathrm{B}_{2} \text { SOCINC }+\mathrm{B}_{3} \text { CONFLICT }+u,
$$

where VOTE is the percentage of the vote for the incumbent party in legislative elections in relation to all valid, null and blank votes; $G R O W T H^{8}$ is the non-linear monotonic transformation of the yearly GDP growth rate described before with a lag of two-quarters; SOCINC is a dummy variable taking the value 1 when the incumbent was

\footnotetext{
${ }^{8}$ To be precise, we estimate the equation VOTE $=\mathrm{B}_{0}+\mathrm{B}_{1}(\text { Linear Growth })^{\alpha}+\mathrm{B}_{2}$ SOCINC $+\mathrm{B}_{3}$ CONFLICT $+u$ by nonlinear least squares. The estimated $\alpha$ is 0.633 . So, our nonlinear measure of growth is simply (Linear Growth) ${ }^{0.633}$
} 
the Socialist Party; CONFLICT is another dummy variable which takes the value 1 for the $1979,1980,1983,1985$ and 2005 elections; and $u$ is a random shock.

\section{Model estimation and evaluation}

\subsection{The data}

Table 1 presents the data used for the model's estimation and evaluation. We start by leaving one of the twelve democratic elections aside, that which took place in 1975 for the constituent assembly, since the incumbent at the time was a provisional government whose composition was unrelated to any electoral outcomes. We do include the 1976 election, however: by then, the provisional government in power was dominated by figures of the Socialist Party, which allows us to treat it as the incumbent. This leaves us with eleven elections. Of those, five took place following coalition governments: 1979, 1980, 1983, 1985 and 2005. In these cases, we considered the vote for the largest and dominant party in the coalition, i.e, the Prime Minister's party, which in all cases was either the PS or the PSD. Finally, in the 1980 elections, the incumbent was a pre-electoral coalition (called Democratic Alliance, AD) between the PSD, the CDS-PP and a very small Monarquist party, which presented itself both for the 1979 and the 1980 elections. In that case, we estimated the vote for the PSD on the basis of the results of the immediately prior and posterior elections. ${ }^{9}$

\section{Table 1 about here}

\footnotetext{
${ }^{9}$ More specifically, we calculated the average proportion of the vote obtained by the PSD in relation to the sum of the vote shares for the three parties in the 1976 and 1983 elections, and estimated the vote for the PSD in 1980 as that proportion applied to the AD vote.
} 


\subsection{The results}

Using OLS, we estimated equation 1, with the following results (t-statistics in parenthesis):

$$
\begin{aligned}
\text { VOTE } & =\underset{(20.73)}{44.89}+\underset{(2.66)}{1.18} \text { GROWTH }-\underset{(-4.30)}{7.79} \text { SOCINC }-\underset{(-10.34)}{19.30} \text { CONFLICT } \\
\mathrm{N} & =11(1976-2005) \quad \mathrm{R}^{2}=0.94 \quad \text { Adj. } \mathrm{R}^{2}=0.92 \quad \mathrm{D}-\mathrm{W}=1.56 \quad \text { SEE}=2.86
\end{aligned}
$$

All coefficients are significant at $\mathrm{p}<0.05$ in a two-tailed test and all have the expected directions: growth increases the vote share of the incumbent party, while Socialist incumbents and those involved in political conflicts with the President tend to be punished. With respect to relative importance, the premier-presidential conflict variable (standardized coefficient: -1.03) clearly edges over the others (-.41 for SOCINC and .26 for GROWTH). As table 1 shows, the two worst performances of the model using the entire sample are in 1980 and in 1995, but all studentized residuals remained well below 2 (with a highest of 1.76 in 1995). The average absolute prediction error within the sample was a mere 1.93 percentage points. With the exclusion of the 1976 election (where the residual was close to zero), five of the residuals show an overestimation of the incumbent's vote, while five others show an underestimation, suggesting no systematic bias. The standard error of the estimate (SEE) suggests that, for a typical future election, the forecast will be off by some 2.9 points.

\subsection{Out-of-sample performance}

We recognize that inference based on such a small sample may be difficult to rely on. One can argue that the lack of degrees of freedom may cause one observation to have a huge impact on the final results, meaning that effects of an outlier are not washed way by a big sample. Therefore, in order to increase the reliability of our results, we perform 
a more demanding analysis and examine the "out-of-sample" forecasts: excluding each election at a time, we re-estimate the model with the remaining observations. Then we check if the estimated coefficients change in a significant way and, of course, how the model forecasts the omitted observation.

In all these re-estimated models, the signs of the coefficients never changed, and only in one case (when the 1976 election was excluded) did one of them (GROWTH) fail to reach statistical significance with $p<0.10$ (although it is still significant if we consider a one tail test). The estimated coefficients were remarkably stable: the minimum estimated value for the INTERCEPT, GROWTH, CONFLICT and SOCINC coefficients were, respectively, 43.96, 0.95, -20.27, -9.28; while the maximum values were $46.42,1.28,-18.44,-6.68$. The standard deviations of the estimated coefficients were, respectively, $0.65,0.10,0.59$ and 0.68 . With such low standard deviations, there are good reasons to believe that the results are reliable.

Table 1 also lists all out-of-sample forecasts and their errors. The largest out-ofsample error was 5.66, underestimating the PSD vote in 1995. But in seven out of eleven cases, the absolute error was lower than three percentage points, and the mean absolute out-of-sample error is 2.84. Although this compares unfavourably, for example, with the out-of-sample performance of most forecast models for the United States presidential elections (Lewis Beck, 2005: 157), it actually fares quite well in comparison with the model devised to forecast the 2001 UK elections (Lewis-Beck, Nadeau and Bélanger, 2004) once the whole 1995-2001 period is included (Bélanger, Lewis-Beck, and Nadeau, 2005). The comparison between our results and the performance of pre-election polls in Portugal is even more flattering. The mean absolute error committed by the polls published in the last week of each election in Portugal from 1991 to 2005 in the estimation of the incumbent's vote share ranges from 1.8 to 6 
percentage points, and the grand mean reaches 3 points (Magalhães, 2005). Interestingly, both the lowest and highest out-of-sample forecast errors committed by our model are below those of the polls, and the mean for those five elections between 1991 and 2005 is, precisely, of 3 percentage points. And this was obtained, note, without including in the model any variables measuring vote intentions and government popularity: just an economic growth indicator measured two quarters before the election and dummies capturing which was the incumbent party and whether elections took place following a politically conflictual relation between the president and the cabinet.

\subsection{Is the small sample a big problem?}

There are two main consequences of a small sample size. The first one is large standard errors, which lead to lower t-statistics, which can lead to incorrect non-rejections of the null hypothesis. The second one is the high sensibility of the estimators to small changes in the sample. Since all our estimated coefficients are highly statistically significant and, as explained before (when performing the out-of-sample forecast experiments), the estimated coefficients are quite insensible to small changes in the sample, this seems not to be a problem. Still, for robustness and to assess the severity of the problem, we used the condition index test (Belsley, 1991).

The condition index test is based on a simple idea. If the sample size is too small $X^{\prime} X$ will be a near singular matrix. In this case, at least one of the eigenvalues of the matrix $X^{\prime} X$ will be close to zero. Therefore, close to zero eigenvalues suggest that the small sample size may be a problem. The test involves the following steps: (1) standardization of the explanatory variables to unit variance; ${ }^{10}(2)$ computation of the eigenvalues of the standardized $X^{\prime} X$; (3) the condition index number is given by

\footnotetext{
${ }^{10}$ This normalization is essential because the test is scale dependent.
} 
$\sqrt{\lambda_{\max } / \lambda_{\min }}$, where $\lambda_{\max }\left(\lambda_{\min }\right)$ is the highest (lowest) eigenvalue. Based on Monte Carlo simulations, Belsley concludes that there is evidence of severe linear dependence between the variables if the index is above 30 . If the index is between 10 and 30 , there is evidence of a moderate to severe sample problem. Computing the condition index of our model, we find a value of 6.79. A value below the suggested bounds, indicating that linear dependence, caused by the small sample, is not a serious concern.

\subsection{Premier-presidential conflict and coalition governments}

The attentive reader may have noticed an aspect of our observations that entails potential problems both for the model we estimated and for the forecasts that may be derived from it. In fact, almost all elections that followed periods of premierpresidential conflict in Portuguese democratic history coincide with elections that followed coalition governments. The only exception is the 1995 election, which was subsequent both to a single-party majority government and to period of acute premierpresidential conflict between President Mário Soares and the cabinet led by PM Cavaco Silva. The obvious question that follows is simple: are the losses experienced by the PM's party in really a function of previous premier-presidential conflict or, instead, of a tendency for coalition governments to be particularly punished in the polls in comparison with other types of cabinets?

We must start by acknowledging that, strictly on the basis of our observations and given the almost perfect collinearity between the two variables, the latter possibility cannot be thoroughly dismissed on strictly empirical grounds. And there is indeed evidence supporting the descriptive inference that the parties composing coalition governments in European democracies have experienced greater electoral losses than minority or majority single-party governments (Strøm 1990: 124). However, it is 
unclear whether coalition government should entail a particular punishment for the dominant party in that coalition, i.e., the PM's party, our dependent variable of interest. Unlike the large vote-seeking parties who tend to play the dominant role in coalitions, smaller parties are in fact the ones that are more likely to experience the electoral costs that arise from the difficulties in reconciling their office-seeking goals with the compromises in policy entailed in participating in a coalition with a larger partner (Strøm and Müller, 1999). As it happens, although coalition governments may in general experience greater losses than other types of cabinet, ${ }^{11}$ we have known for a long time that the most frequent outcome is that the electoral fates of the coalition members differ (Rose and Mackie, 1983). Although the PM's party tends to be punished following oversized coalitions, this is not the case in other types of coalition cabinets (Narud and Valen 2008). And more generally, as it is to be expected, the stronger core parties in the coalition tend to do much better in subsequent elections than the remaining coalition partners (Mershon 2002).

Thus, we find the general argument that coalitions should cause greater losses for the PM's party than other types of cabinets less compelling, both theoretically and empirically, than our argument that such losses are due to premier-presidential conflict. This also flows, with all the acknowledged limitations, from our own observations: if we re-estimate the model replacing the CONFLICT variable with a dummy distinguishing elections following coalition governments (1) and minority or single-

\footnotetext{
${ }^{11}$ In fact, not even this is entirely clear. In a multivariate analysis using electoral data from 17 Western European democracies from 1946 to 1999, Narud and Valen show that such losses are not an effect of the type of cabinet itself, but rather a "mechanic" effect of the tendency of coalitions to have received a larger share of votes and seats than other types: "the more you have - the more there is to lose" (Narud and Valen 2008: 397).
} 
party majority cabinets $(0)$, the model performs significantly worse from all points of view. ${ }^{12}$

\section{A True Out-of-Sample Forecast: the Portuguese General Elections of 2009}

Naturally, any forecasts are subject to errors. Even assuming that the model is perfectly specified, there are two sources of error. The first obvious source is the residual uncertainty. The other source is parameter uncertainty (measured by the standard error of the estimated coefficients). Overall, the forecast standard error is given by $\sqrt{s^{2}+x_{t} s^{2}\left(X^{\prime} X\right)^{-1} x_{t}{ }^{\prime}}$, where $s$ is the standard error of regression, $s^{2}\left(X^{\prime} X\right)^{-1}$ is the covariance matrix of the estimated coefficients and $x_{t}$ is the vector with the values of the independent variables that form the basis of the forecast. With normally distributed residuals, these forecast standard errors can be used to estimate forecasting intervals.

Given the results expressed in equation (2), one can predict the incumbent's party share of votes in the next general elections that will take place in Portugal in the fourth semester of 2009. We can, naturally, consider different scenarios, but we look first at what we believe is the more plausible at the time of this writing. According to the IMF, the predicted GDP growth rate of Portugal for 2009 is 1 percent, ${ }^{13}$ a value of the same magnitude as the predicted GDP growth for 2008 both by the Bank of Portugal and the OECD. Therefore, we will consider, in our basis scenario, a GDP growth between the third semester of 2008 and the second semester of 2009 of 1 percent. So far, there is no open conflict between the government and the President and we anticipate no such conflict in the near future. Finally, there is no uncertainty about our third independent variable: the incumbent party is the PS (the Socialist Party).

\footnotetext{
${ }^{12}$ The SEE increases from 2.86 to 5.18, the adjusted drops from 0.92 to 0.72 and the Mean Absolute Outof Sample residual rises from 3.22 to 5.83 .

${ }^{13}$ International Monetary Fund, Portugal: 2008 Article IV Consultation, Preliminary Conclusions of the Mission, July $14^{\text {th }} 2008$. Available at: http://www.imf.org/external/np/ms/2008/071408.htm.
} 


\section{Table 2 about here}

According to our forecasts, with forecast standard error of 3.22 in our most likely scenario (scenario 1), the incumbent party - the Socialist Party - will receive 39.3 percent of the vote in the 2009 elections. Would this be enough to win the election? In the history of the Portuguese legislative elections, the second most voted party or preelectoral coalition never obtained more than 38 percent of the vote. In other words, a party or pre-electoral coalition that obtained 38 percent or more of the vote has always been the winner. In such a scenario, the PS seems well poised to be the most voted party and thus receive the invitation by the President to form government.

In scenario 2, however, with a more pessimistic economic forecast (no growth), the Socialists' victory becomes more questionable. Assuming stability in the sum of blank, null votes and those for the smaller parties non-represented in parliament in relation to the previous (2005) election (about 5 percent), 37.1 percent would allow the PS to obtain more votes than the PSD only if the sum of the vote shares of the PCP, the BE and the CDS-PP equalled or exceeded 21 percent. This was indeed the case in 2005, but it was neither in 2002 (18 percent) nor 1999 (20 percent). Thus, according to our model, economic performance throughout the second half of 2008 and the first half of 2009 might very well dictate the difference between victory and defeat for the Socialists.

Scenarios 3 and 4 are much less plausible, and serve mostly to illustrate the effects of the different variables. In scenario 3, with a dream economic performance, the Socialist Party would be in the verge of winning an absolute majority of the seats in the Parliament (historically, in Portugal, a share between 43 percent and 44 percent of the 
votes is enough to win 50 percent of the seats). In scenario 4 , we return to our basic scenario, but assume that a conflict between the President and the Government will develop until the election. The effects are huge, as one can see, and the incumbent party would be expected to receive about 20 percent of the vote, i.e, one of its worst electoral performances ever (together with 1985). This shows how, in a semi-presidential regime as the Portuguese one, the presidential powers and the consequences of their exercise may go well beyond what the President's constitutional prerogatives suggest.

\section{Conclusion}

Strong claims that models of election forecasting are really testing theories about electoral behaviour should probably be taken with a grain of salt. Such models rely exclusively on aggregate data, observations are few and the demands of parsimony in order to avoid overfitting can lead to poorly specified models. Furthermore, in our case, and in spite of our best efforts to keep endogenous variables away from the model, we cannot exclude the possibility that one of them - premier-presidential conflict - suffers from such a problem. For example, such conflicts may emerge from the perception that the incumbent is electorally vulnerable on account of some political and economic factor - competence of the prime minister, other aspects of economic performance besides economic growth, and so on - that is unaccounted for in the model. This does not necessarily detract from the model's predictive capacities, but does raise questions about its theoretical soundness. However, forecast models should probably not be seen as mere parlour games either. All attempts at explaining voting behaviour entail an implicit (even if sometimes unacknowledged) claim about prediction (Sanders, 2005), and the ability to confront those claims with actual election results is a very demanding, even if perhaps imperfect, test of extant explanations. At the very least, forecasting 
models can point to interest directions for research and new hypotheses, as well as contribute to change the point of view from which electoral data are conventionally viewed.

From this point of view, we think our results call attention to important aspects of electoral behaviour in Portugal and, perhaps, in several recently established democracies. The literature on voting behaviour in those democracies places great emphasis on electoral volatility and uncertainty, as well as on the impact of short-term factors, especially leaders' evaluations, on the vote. In fact, even the role of the economy in shaping electoral outcomes is sometimes put into question, including in the more consolidated Southern European democracies (Hamann, 2000). On top of this, the increasing availability of polls and trial-heat tracking polls in new democracies favours a kind of approach to elections and their outcomes that pays great attention to campaign events, media coverage and leaders' traits. We are not suggesting such findings or such approaches are necessarily wrong. However, particularly if our model turns out to perform as well with the 2009 election outcomes as well as it performs with past elections, we hope to have called attention to the need to start paying more attention to the elements that seem to stabilize and anchor voting behaviour in Portugal, as well as in other new democracies. Finally, it is often forgotten that, with the "third wave" of democratization, semi-presidentialism has in fact become "the most prevalent system of government in Europe" (Neto and Strøm, 2006: 623). Although semi-presidentialism is a very heterogeneous type of government, there are reasons to believe that, at least in some cases, the dynamics of premier-presidential relations play a crucial role in politics. Portugal is clearly one of such cases, and it is unlikely that it represents a mere outlier. 


\section{References}

Baylis, T., 1996. Presidents versus prime ministers: shaping the executive authority in Eastern Europe, World Politics 48, 297-323.

Bélanger, É., Lewis-Beck, M. S., Nadeau, R., 2005. A political economy forecast for the 2005 British general election, British Journal of Politics and International Relations 7, 191-198.

Belsley, D., 1991. Conditioning Diagnostics: Collinearity and Weak Data in Regression. Wiley Series in Probability and Mathematical Statistics. New York, John Wiley \& Sons.

Bruneau, T. C., Macleod, A., 1986. Politics in Contemporary Portugal: Parties and the Consolidation of Democracy. Lynne Rienner, Boulder.

Campbell, J. E., 2000. Polls and votes: the trial-heat presidential election forecasting model, certainty, and political campaigns. In Campbell, J. E., Garand, J. (Eds.), Before the Vote: Forecasting American National Elections. Sage, Thousand Oaks, pp. 17-46.

Campbell, J.E., 2008. Evaluating U.S. presidential election forecasts and forecasting equations. International Journal of Forecasting 24, 259-271.

Corkill, D., 1996. Portugal votes for change and stability: the election of 1995, West European Politics 19, 403-409.

Duverger, M., 1980. A new political system model: semi-presidential government, European Journal of Political Research 8, 165-87.

Fair, R., 1978. The effect of economic events on votes for president, Review of Economics and Statistics 64, 159-172.

Frain, M., 1995. Relações entre o presidente e o primeiro-ministro em Portugal: 19851995, Análise Social 133, 653-678.

Freire, A., 2007. Issue voting in Portugal. In: Freire, A., Lobo, M. C., Magalhães, P. (Eds.), Portugal at the Polls in 2002. Lexington Books, Lanham, MD, pp. 101124.

Gómez Fortes, B., 2007. Os eleitores de esquerda perante o Partido Socialista: duros e pragmáticos. In: Freire, A., Lobo, M. C., Magalhães, P. (Eds.), Eleições e Cultura Política. Imprensa de Ciências Sociais, Lisboa, pp. 59-90.

Gunther, R., 2005. Parties and electoral behaviour in Southern Europe, Comparative Politics 37, 253-274.

Gunther, R., Montero, J.R., 2001. The anchors of partisanship. In: Diamandouros, N., Gunther, R. (Eds.), Parties, Politics and Democracy in the New Europe. Johns Hopkins, Baltimore, pp. 83-152.

Hibbs, D. A. Jr., 1977. Political parties and macroeconomic policy, American Political Science Review 71, 1467-1487.

Jérôme, B., Jérôme-Spéziari, V., 2004. Forecasting the 2002 elections: lessons from a political economy model. In: M. S. Lewis-Beck (Ed.), The French Voter: Before and After the 2002 Elections. Palgrave Macmillan, Basingstoke, pp. 178-204.

Kramer, G. H., 1971. Short-term fluctuations in U.S. voting behaviour, 1896-1964 American Political Science Review 65: 131-143.

Kristinsson, G. H., 1999. Iceland. In: Elgie, R. (Ed.), Semi-presidentialism in Europe. Oxford University Press, Oxford, pp. 86-104.

Laakso, M., Taagepera, R., 1979. 'Effective' number of parties: a measure with application to West Europe, Comparative Political Studies 12, 3-27.

Lebo, M. J, Norpoth, H., 2007. The PM and the pendulum: dynamic forecasting of British elections. British Journal of Political Science 37, 71-87. 
Lewis-Beck, M. S., 2005. Election forecasting: principles and practice. British Journal of Politics and International Relations 7, 145-164.

Lewis-Beck, M. S., Bélanger, E., Fauvelle-Aymar, C., 2008. Forecasting the 2007 French presidencial election: Ségolène Royal and the Iowa model, French Politics 6, 106-115.

Lewis-Beck, M. S., Nadeau, R., Bélanger, É., 2004. General election forecasts in the United Kingdom, Electoral Studies 23: 279-290.

Lewis-Beck, M. S., Rice, T. W., 1992. Forecasting Elections. Washington, Congressional Quarterly.

Lloyd-Jones, S., 2002. The 1999 parliamentary elections and 2001 presidential elections in Portugal. Electoral Studies 21, 144-122.

Lobo, M. C., 2006. Short-term voting determinants in a young democracy: leader effects in Portugal in the 2002 legislative elections. Electoral Studies 25, 270286.

Magalhães, P. C., 2005. Pre-election polls in Portugal: accuracy, bias and sources of error. International Journal of Public Opinion Research 17, 399-421.

Magalhães, P. C., 2007. What are (semi)presidential elections about? A case study of the Portuguese 2006 elections. Journal of Elections, Public Opinion and Parties $17,163-291$.

Mainwaring, S., Torcal, M., 2006. Party system institutionalization and party system theory after the third wave of democratization. In: Katz, R., Crotty, W. (Eds.), Handbook of Political Parties. Sage Publications, London, pp. 204-227.

Mershon, C., 2002. The Costs of Coalition. Stanford University Press, Stanford.

Mughan, A., 1987. General election forecasting in Britain: a comparison of three simple models. Electoral Studies 6, 195-207.

Müller, W., 1999. Austria. In: Elgie, R. (Ed.), Semi-presidentialism in Europe. Oxford University Press, Oxford, pp. 22-47.

Narud, H. M., Valen, H., 2008. Coalition membership and electoral performance. In: Strøm, K., Müller, W. C., Bergman, T. (Eds.), Cabinets and Coalition Bargaining: The Democratic Lyfe Cycle in Western Europe. Oxford University Press, Oxford, pp. 369-402.

Neto, O. A., 2003. Portugal: changing patterns of delegation and accountability under the president's watchful eyes. In: Strøm, K., Müller, W., Bergman, T. (Eds.), Delegation and Accountability in Parliamentary Democracies. Oxford University Press, Oxford, pp. 552-572.

Neto, O. A., Strøm, K., 2006. Breaking the parliamentary chain of delegation: presidents and non-partisan cabinet members in European democracies. British Journal of Political Science 36, 619-643.

Norpoth, H., Gschwend, T., 2003. Against all odds? The red-green victory, German Politics and Society 21, 15-34.

Powell, G.B. Jr., Whitten, G. D., 1993. A cross-national analysis of economic voting: taking account of the political context, American Journal of Political Science 37, 391-414.

Protsyk, O., 2005. Politics of intraexecutive conflict in semipresidential regimes in eastern Europe, East European Politics and Societies 19, 135-160.

Protsyk, O., 2006. Intra-executive competition between president and prime minister: patterns of institutional conflict and cooperation under semi-presidentialism, Political Studies 56, 219-244. 
Rose, R., Mackie, T. T., 1983. Incumbency in government: asset or liability? In: Daalder, H., Mair, P. (Eds.), Western European Party Systems: Continuity and Change. Sage Publications, London, pp.115-137.

Salgado, S., 2007. Parliamentary and presidential elections in Portugal, 2005-2006. Electoral Studies 26, 512-516.

Sanders, D., 2005. The political economy of UK party support, 1997-2004: forecasts for the 2005 general election., Journal of Elections, Public Opinion and Parties 15, 4771.

Shugart, M. S., 2006. Comparative executive-legislative relations. In: Rhodes, E. A. W., Binder, S. A., Rockman, B. A. (Eds.), The Oxford Handbook of Political Institutions. Oxford University Press, Oxford, pp. 344-365.

Strøm, K., 1990. Minority Government and Majority Rule. Cambridge University Press, Cambridge.

Strøm, K., Müller, W. C., 1999. Political parties and hard choices. In: Müller, W. C., Strøm, K. (Eds.), Policy, Office, or Votes: How Political Parties in Western Europe Make Hard Decisions. Cambridge University Press, Cambridge, pp. 1-35.

Thiébault, J.-L., 2003. France: delegation and accountability in the Fifth Republic. In: Strøm, K., Müller, W., Bergman, T. (Eds.), Delegation and Accountability in Parliamentary Democracies. Oxford University Press, Oxford, pp. 325-346.

Van der Brug, W., Van der Eijk, C., Franklin, M., 2007. The Economy and the Vote: Economic Conditions and Elections in Fifteeen Countries. Cambridge University Press, Cambridge.

Van der Eijk, C., 2005. Election forecasting: a sceptical view. British Journal of Politics and International Relations 7, 210-214.

Veiga, F. J., Veiga, L. G., 2004a. Popularity functions, partisan effects, and support in parliament, Economics and Politics 16, 101-115.

Veiga, F. J., Veiga, L. G., 2004b. The determinants of vote intention in Portugal, Public Choice 118, 341-364.

Whiteley, P.F., 1979. Electoral forecasting from poll data: the British case, British Journal of Political Science 9, 219-236.

Whiteley, P., 2008. Evaluating rival forecasting models of the 2005 general election in Britain: an encompassing experiment, Electoral Studies 27, 581-588. 
Figure 1:

Nonlinear growth rate

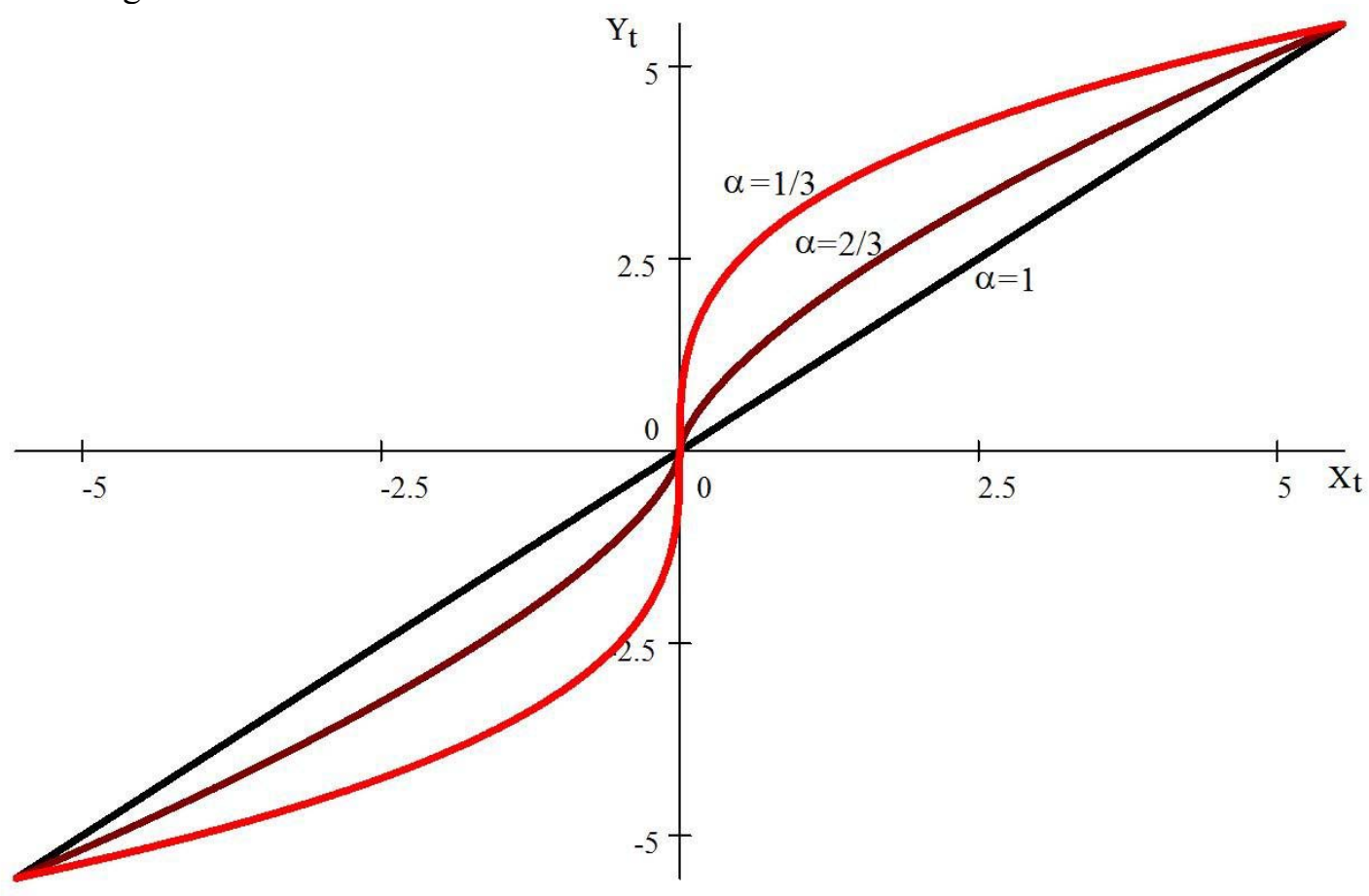


Table 1

Variables' values and within-sample and out-of-sample forecasts

\begin{tabular}{|c|c|c|c|c|c|c|c|c|}
\hline Election & $\begin{array}{c}\text { Yearly real } \\
\text { GDP growth } \\
\text { rate } \\
\text { (lagged } q-2 \text { ) } \\
\end{array}$ & $\begin{array}{c}\text { Premier- } \\
\text { presidential } \\
\text { conflict }\end{array}$ & $\begin{array}{c}\text { Socialist } \\
\text { incumbent }\end{array}$ & $\begin{array}{c}\text { Incumbent } \\
\text { vote share } \\
(\%)\end{array}$ & $\begin{array}{c}\text { Predicted } \\
\text { vote share } \\
(\%)\end{array}$ & Residual & $\begin{array}{c}\text { Out-of- } \\
\text { sample } \\
\text { forecast } \\
(\%) \\
\end{array}$ & $\begin{array}{l}\text { Forecast } \\
\text { Residual }\end{array}$ \\
\hline Apr. $15^{\text {th }}, 1976$ & -1.08 & 0 & 1 & 34.89 & 34.79 & 0.10 & 34.47 & 0.42 \\
\hline Dec. $2^{\text {nd }}, 1979$ & 5.55 & 1 & 1 & $27.33^{\mathrm{a}}$ & 24.33 & 3.00 & 22.15 & 5.18 \\
\hline Oct. $5^{\text {th }}, 1980$ & 5.02 & 1 & 0 & $28.57^{\mathrm{a} / \mathrm{b}}$ & 31.72 & -3.15 & 32.68 & -4.11 \\
\hline April $25^{\text {th }}, 1983$ & 2.34 & 1 & 0 & $27.24^{\mathrm{a}}$ & 29.38 & -2.14 & 30.04 & -2.80 \\
\hline Oct. $6^{\text {th }}, 1985$ & 4.29 & 1 & 1 & $20.77^{\mathrm{a}}$ & 23.35 & -2.58 & 24.83 & -4.06 \\
\hline July, $19^{\text {th }}, 1987$ & 5.16 & 0 & 0 & 50.22 & 51.13 & -0.91 & 51.89 & -1.67 \\
\hline Oct. $6^{\text {th }}, 1991$ & 2.95 & 0 & 0 & 50.6 & 49.27 & 1.33 & 48.55 & 2.05 \\
\hline Oct. $1^{\text {st }}, 1995$ & 2.69 & 1 & 0 & 34.12 & 29.73 & 4.39 & 28.46 & 5.66 \\
\hline Oct. $10^{\text {th }}, 1999$ & 4.44 & 0 & 1 & 44.06 & 42.77 & 1.29 & 41.97 & 2.09 \\
\hline Mar. $17^{\text {th }}, 2002$ & 1.22 & 0 & 1 & 37.79 & 39.60 & -1.81 & 40.27 & -2.48 \\
\hline Feb. $20^{\text {th }} 2005$ & 1.37 & 1 & 0 & $28.77^{\mathrm{a}}$ & 28.29 & 0.48 & 28.09 & 0.68 \\
\hline
\end{tabular}

${ }^{\mathrm{a}}$ Vote for major party of incumbent coalition; ${ }^{\mathrm{b}}$ Estimated 
Table 2

Forecasts for the incumbent's vote share in the 2009 elections under different scenarios

\begin{tabular}{ccccc}
\hline & Scenario 1 & Scenario 2 & Scenario 3 & Scenario 4 \\
\hline GDP growth & 1 & 0 & 5 & 1 \\
Conflict & 0 & 0 & 0 & 1 \\
SocInc & 1 & 1 & 1 & 1 \\
Forecast (\%) & 39.3 & 37.1 & 43.2 & 20.0 \\
Forecast std. error & 3.2 & 3.4 & 3.4 & 3.4 \\
\hline
\end{tabular}

